\title{
KONSEKUENSI YURIDIS SALINAN AKTA NOTARIS \\ YANG TIDAK SAMA BUNYINYA DENGAN MINUTA AKTA \\ TERHADAP KEABSAHAN PERJANJIAN
}

\section{Dedy Prasetyo Winarno}

\author{
Dinas Koperasi Surabaya \\ JL. Gayungsari, No. 01 \\ Email: dedy.indopreneur@yahoo.com
}

\begin{abstract}
The provisions of Article 16 paragraph (1) letter d of Law No. 2 of 2014 states that a copy of the certificate issued by the minutes deed, Article 1 point 9 of Law No. 2 of 2014 on the copy of the certificate, which is a copy of the verbatim of the entire deed on the bottom copy of the deed listed The phrase "given as the same copy sound". The position of the original copy of a notarial deed which can be used as evidence perfect be imperfect because the copy does not sound the same deed with a deed minuta, so it does not meet the formal requirements and substantive procedures deed. This resulted in a copy of the deed declared null and void. Juridical consequences of the agreement in a copy of the certificate, namely: the agreement can be declared null and void because it causes damages to the parties and contains elements of fraud and notary oversight and sanctions if the notary has abused his power. Method used in this thesis is normative. The purpose of this paper is to describe and analyze the position of the copy of the deed that does not sound the same with the minutes of the deed. While the benefits of this paper is expected to contribute good ideas to the law enforcement, and public notaries.
\end{abstract}

Key words: notary, minuta deed and deed copies

\begin{abstract}
Abstrak
Ketentuan Pasal 16 ayat (1) huruf d UU Nomor 2 Tahun 2014 menyebutkan bahwa salinan akta dikeluarkan berdasarkan minuta akta, Pasal 1 angka 9 UU Nomor 2 Tahun 2014 tentang Salinan akta, yaitu salinan kata demi kata dari seluruh akta pada bagian bawah salinan akta tercantum Frasa "diberikan sebagai salinan yang sama bunyinya". Kedudukan dari salinan akta notaris yang semula dapat digunakan sebagai alat bukti yang sempurna menjadi tidak sempurna dikarenakan salinan akta tersebut tidak sama bunyinya dengan minuta akta, sehingga tidak memenuhi syarat formil dan materiil prosedur pembuatan akta. Hal ini mengakibatkan salinan akta tersebut dinyatakan batal demi hukum. Konsekuensi yuridis perjanjian dalam salinan akta tersebut, yaitu: perjanjian dapat dinyatakan batal demi hukum karena mengakibatkan kerugian bagi para pihak dan mengandung unsur kekhilafan dan penipuan dan notaris memiliki sanksi apabila notaris tersebut menyalahgunakan wewenangnya. Metode penulisan yang digunakan dalam penulisan tesis ini adalah yuridis normatif. Adapun tujuan dalam penulisan ini adalah untuk mendeskripsikan dan menganalisa kedudukan dari salinan akta yang tidak sama bunyinya dengan minuta akta. Sedangkan manfaat dari penulisan ini diharapkan dapat memberikan sumbangan pemikiran baik kepada para penegak hukum, notaris maupun masyarakat.
\end{abstract}

Kata kunci: notaris, minuta akta dan salinan akta 


\section{Latar Belakang}

Kewenangan notaris dituangkan dalam Pasal 15 UU Nomor 2 Tahun 2014, yaitu:

(1) Notaris berwenang membuat akta otentik mengenai semua perbuatan, perjanjian, dan ketetapan yang diharuskan oleh peraturan perundang-undangan, dan/atau yang dikehendaki oleh yang berkepentingan untuk dinyatakan dalam akta otentik, menjamin kepastian tanggal pembuatan akta, menyimpan akta, memberikan grosse, salinan dan kutipan akta, semuanya itu sepanjang pembuatan akta-akta itu tidak juga ditugaskan atau dikecualikan kepada pejabat lain atau orang lain yang ditetapkan oleh undang-undang.(2) Berdasarkan Pasal 15 UU Nomor 2 Tahun 2014 , kewenangan yang paling utama seorang notaris adalah membuat akta yang berbentuk otentik dengan batasan: ${ }^{1}$ Undang-undang telah mengatur pejabat lain untuk membuat akta tanpa ada perkecualian, bahwa notaris harus membuat akta mengenai semua perbuatan, perjanjian dan penetapan yang diharuskan oleh suatu peraturan umum atau yang sesuai dengan kehendak para pihak, berkaitan dengan subyek hukum (baik orang atau badan hukum), untuk kepentingan siapa akta dibuat atau dikehendaki, berkaitan dengan tempat kedudukan dan wilayah jabatan, notaris berwenang terhadap tempat di mana akta dibuat, berkaitan denganwaktupembuatan akta, notaris harus menjamin kepastian hari, tanggal dan jam yang tercantum dalam akta.

Bukan hanya kewenangan saja yang harus diperhatikan Notaris dalam melaksanakan tugas dan jabatannya, namun ada salah satu kewajiban Notaris yang tertera dalam Pasal 16 ayat (1) huruf dUU Nomor 02 Tahun 2014 bahwa notaris wajib mengeluarkan salinan akta berdasarkan minuta akta. Salinan akta merupakan turunan dari minuta akta, lebih lengkapnya mengenai pengertian salinan akta diatur dalam Pasal 1 UU Nomor 02 Tahun 2014, salinan akta adalah salinan kata demi kata dari seluruh akta dan pada bagian bawah salinan akta tercantum frasa "diberikan sebagai SALINAN yang sama bunyinya. Pengertian "Minuta akta atau minit adalah akte yang asli yang ditandatangani oleh penghadap, saksisaksi dan notaris dan disimpan dalam arsip notaris (bukan salinan atau kutipan dan juga bukan grosse)".2

Pentingnya penelitian ini adalah untuk memberikan kesadaran kepada notaris yang tidak melaksanakan tugas jabatannya sesuai dengan yang diatur dalam UU Nomor 30 Tahun 2004 dan UU Nomor 2 Tahun 2014 dan untuk mengembalikan citra notaris yang mulai luntur dikarenakan banyaknya oknum notaris yang melakukan pelanggaran. Padahal jabatan notaris merupakan jabatan yang diberikan atas dasar kepercayaan dari

1 Habib Adjie, Sanksi Perdata dan Administratif terhadap Notaris sebagai Pejabat Publik, Refika Aditama, Bandung, 2008, hlm. 56.

2 R. SoegondoNotodisoerjo, Hukum Notariat di Indonesia, RajaGrafindo Persada, Jakarta, 1993, hlm. 176. 
masyarakat dan pemeritah.Dikarenakan atas dasar kepercayaan tersebut, maka jabatan notaris merupakan jabatan yang luhur dan bermartabat. Selain itu, salinan notaris yang dapat membuktikan kebenaran yang ada dalam minuta akta dikarenakan notaris hanya boleh membuat dan mengeluarkan salinan akta kepada pihak-pihak yang terkait di dalam akta tersebut dan notaris dilarang untuk mengeluarkan dan memberitahukan minuta akta kepada pihak lain sehingga apabila ada pihak-pihak yang bersengketa, salinan notaris tersebut yang dapat dijadikan bukti bagi pihak tersebut. Sehingga apabila salinan notaris tidak sama persis dengan minuta akta maka dapat menimbulkan kerugian bagi notaris itu sendiri maupun bagi pihak yang bersengketa. Dalam Pasal 16 ayat (1) huruf d UU Nomor 2 Tahun 2014 menyebutkan bahwasalinan akta dikeluarkan berdasarkan minuta akta dan diatur pula dalam Pasal 1 angka 9 UU Nomor 2 Tahun 2014 tentang pengertian Salinan akta, yaitu salinan kata demi kata dari seluruh akta pada bagian bawah salinan akta tercantum Frasa "diberikan sebagai salinan yang sama bunyinya".

Metode penulisan yang digunakan dalam penulisan tesis ini adalah yuridis normatif. Adapun tujuan dalam penulisan ini adalah untuk mendeskripsikan dan menganalisa kedudukan dari salinan akta yang tidak sama bunyinya dengan minuta akta. Sedangkan manfaat dari penulisan ini diharapkan dapat memberikan sumbangan pemikiran baik kepada para penegak hukum, notaris maupun masyarakat.

\section{A. Konsekuensi Yuridis Salinan Akta Notaris Yang Tidak Sama Bunyinya Dengan Minuta Akta Terhadap Keabsahan Perjanjian}

\section{Analisis kedudukan dari salinan akta notaris yang tidak sama bunyinya dengan minuta akta notaris}

\section{a. Akta batal demi hukum}

Arti dari Minuta (minit) adalah akte yang asli yang ditandatangani oleh para penghadap, saksi-saksi dan Notaris dan di simpan dalam arsip Notaris.Jadi bukan salinan (turunan) atau kutipan dan juga bukan grosse akta. ${ }^{3}$ Kutipan dapat disebut juga sebagai turunan dari sebagaian kata, jadi merupakan turunan tidak lengkap.Kutipan ini diambil dari sebagian Minuta Akta, pengutipan dilakukan sesuai dengan permintaan yang bersangkutan, dalam arti bagian mana yang harus dikutip.Dalam akta dan akhir akta tetap harus ada.Kutipan dari Minuta Akta tersebut ditempatkan pada isi akta, dan pada akhir akta dituliskan diberikan sebagai kutipan. ${ }^{4}$

3 R. SoegondoNotodisoerjo, Hukum Notariat Di Indonesia (Suatu Penjelasan), Cetakan Pertama, RajaGrafindo Persada, Jakarta, 1993, hlm. 176.

4 Habib Adjie, Op.cit., hlm. 47. 
Dari semua akta yang dibuat dalam bentuk minuta akta, Notaris berwenang dan sekaligus berkewajiban untuk mengeluarkan salinan, kutipan, grose akta dan memperlihatkan atau memberitahukan isi akta kepada yang langsung berkepentingan dalam akta tanpa batasan jumlah salinan, kutipan akta, kecuali untuk grosse akta dengan irah-irah "DEMI KEADILAN BERDASARKAN KETUHANAN YANG MAHA ESA" Notaris hanya dapat mengeluarkan 1 (satu) grosse akta pertama kepada yang langsung berkepentingan dalam akta sedangkan untuk grosse akta kedua dan selanjutnya hanya kepada yang langsung berkepentingan dalam akta berdasarkan penetapan pengadilan sebagaimana ditetapkan dalam Pasal 55 ayat (4) UU Nomor 2 Tahun 2014.

Adapun kewajiban notaris untuk mengeluarkan grosse akta, salinan akta atau kutipan akta berdasarkan minuta ditentukan dalam Pasal 16 ayat (1) huruf d UU Nomor 2 Tahun 2014, dan mengenai pengertian dari salinan akta itu sendiri juga diatur dalam Pasal 1 ayat (9) UU Nomor 2 Tahun 2014 yang menyatakan bahwa salinan akta merupakan salinan kata demi kata dari seluruh akta dan pada bagian bawah salinan akta tercantum frasa diberikan sebagai SALINAN yang sama bunyinya.

Dalam kaitan dengan ini, khususnya mengenai kalimat berdasarkan minuta dan diberikan sebagai SALINAN yang sama bunyinya dalam rumusan pasal tersebut, maka notaris harus mengeluarkan salinan setelah minuta akta dibuat dan bunyi dari salinan tersebut harus sama dengan bunyi minuta akta tanpa dikurangi maupun ditambah. Kecuali, akhir akta dari salinan harus dicantumkan frasa sebagai salinan yang sama bunyinya dan hanya ada tanda tangan dari notaris yang membuat akta tersebut.

Sebagaimana yang telah disebutkan di atas, apabila salinan akta tidak sama bunyinya dengan minuta akta, maka akta tersebut tidak memenuhi syarat materiil dari suatu akta notaris dan dapat dinyatakan menjadi batal demi hukum oleh hakim. Hal ini disebabkan karena salinan akta juga merupakan akta otentik yang wajib dikeluarkan oleh notaris untuk pihak-pihak yang berkepentingan dan dapat digunakan sebagai alat bukti bagi pihak-pihak yang terkait, sedangkan minuta akta yang merupakan asli akta harus disimpan notaris sebagai protokol notaris. Mempertimbangkan analisis di atas, apabila pejabat umum dalam hal ini notaris membuat salinan akta yang bunyinya tidak sama dengan minuta akta maka notaris tersebut telah keluar dari batas kewenangannya yaitu melanggar Pasal 16 ayat (1) huruf d UU Nomor 2 Tahun 2014, dan Pasal 1 ayat (9) UU Nomor 2 Tahun 2014 yang merupakan pengertian dari salinan akta itu sendiri.

Adanya ketidaksamaan bunyi salinan akta dan minuta akta merupakan salah satu akibat hilangnyaotensitas akta atau batalnya suatu akta notaris. Hal ini dapat dapat menyebabkan 
akibat yang bervariasi kepada pihak yang berkepentingan, yaitu: ${ }^{5}$ 1) Hilangnya otensitas akta atau akta notaris ikut batal, dan tindakan hukum yang tertuang di dalamnya ikut batal, hal ini terjadi perbuatan hukum yang oleh undang-undang diharuskan dituangkan dalam suatu akta otentik. Misalnya: akta pendirian perseroan terbatas. 2. Hilangnya otensitas akta tetapi akta notaris tidak batal dan perbuatan hukum yang tertuang di dalamnya tidak ikut batal. Hal ini terjadi pada perbuatan hukum yang tidak diwajibkan oleh undang-undang untuk dituangkan di dalam suatu akta otentik, tetapi pihak-pihak menghendaki perbuatan hukum mereka dapat dibuktikan dengan suatu akta otentik, supaya dapat diperoleh suatu pembuktian yang kuat. 3. Akta tetap memiliki otensitas (akta notarisnya batal) atau tindakan hukum yang tertuang di dalamnya batal. Hal ini terjadi jika syarat-syarat perjanjian tidak dipenuhi atau terjadinya cacat dasar hak yang menjadi objek perjanjian.Misalnya jual beli dilakukan atas bukti palsu.

Ketidaksamaan bunyi antara minuta akta dan salinan akta dapat mengurangi nilai pembuktian akta otentik dalam aspek formal. Karena apa yang tersebut dalam akta merupakan pembuktian yang sah terhadap pihak-pihak yang membuat akta atau pihak yang mendapatkan hak dalam akta tersebut dan berlaku untuk umum, kecuali ada pembuktian sebaliknya. Keterangan yang dituangkan dalam akta atau yang disampaikan di hadapan notaris oleh para pihak harus dinilai benar. Sehingga isi akta notaris mempunyai kepastian sebagai yang sebenarnya, dapat dijadikan bukti yang sah bagi para pihak dan para ahli waris serta para pihak yang menerima hak atas akta tersebut.

Akta notaris yang mempunyai kekuatan pembuktian sebagai akta di bawah tangan atau akan menjadi batal demi hukum, dapat dilihat dan ditentukan dari: 1. Isi dalam pasal-pasal tertentu yang menegaskan secara langsung jika notaris melakukan pelanggaran maka akta yang bersangkutan termasuk akta yang memiliki kekuatan pembuktian sebagai akta di bawah tangan. Misalnya: Dalam Pasal 15 ayat (9) menyatakan bahwa jika salah satu syarat sebagimana dimaksud pada ayat (1) huruf m dan ayat (7) tidak dipenuhi maka akta yang bersangkutan hanya mempunyai kekuatan pembuktian sebagai akta di bawah tangan. 2. Jika tidak disebutkan dengan tegas dalam pasal yang bersangkutan sebagai akta yang memiliki pembuktian sebagai akta di bawah tangan maka termasuk dalam akta batal demi hukum.

Salinan akta yang tidak memiliki kesamaan bunyi dengan minuta akta dapat dinyatakan batal demi hukum oleh hakim setelah ada gugatan dari pihak-pihak yang menanggung kerugian atas akta tersebut karena selain tidak disebutkan secara tegas dalam pasal yang bersangkutan tentang akibat dari salinan akta yang tidak sama bunyinya dengan minuta 
akta, juga tidak dipenuhinya syarat-syarat yang sudah ditentukan menurut hukum, yaitu salinan akta tidak dibuat berdasarkan minuta akta dan salinan akta dibuat dengan tidak sama bunyinya. Di mana hal ini, telah melanggar Pasal 1 angka 9 dan Pasal 16 ayat (1) huruf d UU Nomor 2 Tahun 2015. Dengan demikian, salinan akta maupun minutanya dapat digolongkan sebagai akta yang cacat hukum.

Dari uraian di atas, penulis menganalisa bahwa bunyi salinan akta yang tidak sama dengan minuta akta dapat membuat kedudukan dari akta tersebut tidak sah dan tidak memiliki kekuatan pembuktian yang sempurna, hal ini dikarenakan dalam pembuatan akta tersebut tidak sesuai dengan tatacara yang telah diatur dalam UU Nomor 2 Tahun 2014 yaitu Perubahan Atas UU Nomor 30 Tahun 2004 tentang Peraturan Jabatan Notaris. Dalam hal ini para pihak dapat membatalkan isi dari akta tersebut dengan cara membuat akta pembatalan di kantor notaris atau mengajukan gugatan ke pengadilan.

\section{b. Akta dapat dibatalkan}

Hukum perjanjian memiliki akibat hukum tertentu jika syarat subjektif dansyarat objektif tidak dipenuhi.Jika syarat subjektif tidak terpenuhi, maka perjanjiandapat dibatalkan sepanjang ada permintaan oleh orang-orang tertentu atau yangberkepentingan.Syarat subjektif ini senantiasa dibayangi ancaman untuk dibatalkanoleh para pihak yang

6 Herlien Budiono, Op.cit., hlm. 368. berkepentingan dari orang tua, wali atau pengampu. Agarancaman seperti itu tidak terjadi, maka dapat dimintakan penegasan dari mereka yangberkepentingan, bahwa perjanjian tersebut akan tetap berlaku dan mengikat parapihak.

Adapun faktor-faktor yang dapat menyebabkan suatu kedudukan hukum akta menjadi batal atau dapat dibatalkan adalah sebagai berikut: 1) Ketidakcakapan dan Ketidakwenangan Dalam Bertindak. Secara umum dibedakan antara kewenangan bertindak dan kecakapanbertindak.Sejak seorang anak lahir, malahan anak dalam kandungan dianggapsebagai telah dilahirkan berkedudukan sebagai subjek hukum dan sebab itu pulamemiliki kewenangan hukum (Pasal 1 ayat (2) KUHPerdata).Kewenangan bertindakdari subjek hukum untuk melakukan tindakan hukum dapat dibatasi oleh atau melaluihukum.Setiap orang dianggap cakap melakukan tindakan hukum, tetapi kebebasanini dibatasi pula oleh daya kerja hukum objektif. Dikatakan mereka yang tidak mempunyai kecakapan bertindak atau tidakcakap adalah orang yang secara umum tidak dapat melakukan tindakan hukum. Bagi mereka yang di bawah umur batasan tertentu dikaitkan dengan ukuran kuantitas, yaitu usia. Sebagai penghadap untuk pembuatan akta Notaris harus memenuhi syarat palingsedikit berumur 18 tahun (Pasal 39 ayat (1) Undang-undang Nomor 30 Tahun 2004 tentang Jabatan Notaris). ${ }^{6}$ Mereka yang 
tidak mempunyai kewenangan bertindak atau tidak berwenangadalah orang yang tidak diperbolehkan untuk melakukan tindakan hukum tertentu.Notaris (termasuk para saksi) yang dengan perantaraannya telah dibuat aktawasiat dari pewaris tidak boleh menikmati sedikit pun dari apa yang pada merekadengan wasiat itu telah dihibahkannya (Pasal 907 KUHPerdata). Ini berarti bahwaNotaris tersebut boleh saja mendapat hibah wasiat dari orang lain asal bukan dariklien yang membuat wasiat di hadapannya tersebut. ${ }^{7}$ 1) Cacat Dalam Kehendak. Ketentuan Pasal 1322 - Pasal 1328 KUHPerdata menetapkan secaralimitatif adanya cacat kehendak, yakni kekhilafan/kesesatan (dwaling), penipuan(bedrog), dan paksaan (dwang). ${ }^{8}$ 2) Kekeliruan dan Penipuan. Dikatakan penipuan apabila seseorang dengan sengaja dengan kehendak danpengetahuan memunculkan kesesatan pada orang lain. Penipuan dikatakan terjaditidak saja bilamana suatu fakta tertentu dengan sengaja tidak diungkapkan ataudisembunyikan, tetapijuga suatuinformasi keliru dengan sengaja diberikan ataupunterjadi dengan tipu daya lain. c) Ancaman. Ancaman terjadi bilamana seseorang menggerakkan orang lain untukmelakukan suatu tindakan hukum, yakni dengan melawan hukum, mengancam, danmenimbulkan kerugian pada diri orang tersebut atau kebendaan miliknya atauterhadap pihak ketiga. Ancaman tersebut sedemikian menimbulkan ketakutansehingga kehendak seseorang terbentuk secara cacat. Kehendak betul telahdinyatakan, tetapi kehendak tersebut muncul sebagai akibat adanya ancaman. d) Penyalahgunaan Keadaan. Penyalahgunaan keadaan adalah keadaan tergeraknya seseorang karena suatu keadaan khusus untuk melakukan tindakan hukum dan pihak lawan menyalah gunakan hal ini. Larangan yang ditetapkan undang-undang berkenaan dengan perjanjian akan berkaitan dengan tiga aspek dari perbuatan hukum yang dimaksud, yakni:a) Pelaksanaan dari tindakan hukum, b) Substansi dari tindakan hukum, c) Maksud dan tujuan tindakan hukum tersebut.

\section{Analisis konsekuensi yuridis perjanjian yang salinan akta tidak sama dengan minuta akta}

\section{a. konsekuensi terhadap status perjanjian dalam akta}

Sudikno Mertokusumo berpendapat akta adalah surat yang diberi tanda tangan, yang di dalamnya memuat peristiwa atau kejadian yang menjadi dasar atas suatu hak, yang dibuat sejak semula secara sengaja untuk pembuktian. ${ }^{9}$ Sedangkan, Subekti memiliki pendapat bahwa akta berbeda dengan surat. Kata "Akta" berasal dari kata Acte yang dalam bahasa Perancis berarti perbuatan sehingga akta bukan berarti surat melainkan harus diartikan sebagai perbuatan hukum. ${ }^{10}$

7 Ibid., hlm. 370.

8 Ibid., hlm. 372.

9 SudiknoMertokusumo, Mengenal Hukum Suatu Pengantar, Liberty, Yogyakarta, 1999, hlm. 157.

10 Subekti, Pokok-pokok Hukum Perdata, Intermasa, Jakarta, 1980, hlm. 29. 
Selanjutnya berkaitan dengan akta notaris, maka fungsi akta bagi para pihak yang berkepentingan adalah: ${ }^{11}$ a. Sebagai syarat untuk menyatakan adanya suatu perbuatan hukum; b. Sebagai alat pembuktian; c. Sebagai alat pembuktian satu-satunya. Akta termasuk salah satu bukti tulisan yang di dalamnya memuat suatu perbuatan hukum antara para pihak dan bertujuan untuk digunakan sebagai alat bukti.Mengenai hal ini menurut Pasal 1867 KUH Per, pembuktian dengan tulisan harus dilakukan dengan tulisan-tulisan otentik maupun tulisan-tulisan di bawah tangan. Sehingga akta sebagai bukti terdiri dari akta otentik dan akta di bawah tangan.

Dari kewenangan notaris, dapat dianalisa bahwa notaris memperoleh kewenangan dari undang-undang dengan tujuan untuk menuangkan semua perbuatan, perjanjian dan penetapan yang dikehendaki oleh pihak atau pihak-pihak yang sengaja datang ke hadapan notaris untuk menuangkan kembali keterangan tersebut ke dalam suatu akta otentik, dan agar akta yang dibuatnya itu memiliki kekuatan bukti yang lengkap dan memiliki keabsahan. ${ }^{12}$ Notaris memiliki kewajiban untuk mengetahui dan memahami syarat-syarat otensitas, keabsahan dan sebabsebab kebatalan suatu akta notaris.Hal ini sangat penting karena untuk menghindari adanya cacat hukum akta notaris yang dapat mengakibatkan hilangnyaotensitas dan batalnya akta notaris yang dapat merugikan kepentingan masyarakat, khususnya pihakpihak yang berkepentingan.

Istilah perjanjian juga dapat diartikan sebagai suatu peristiwa di mana seorang berjanji kepada seorang lain, atau di mana dua orang saling berjanji untuk melaksanakan sesuatu. ${ }^{13}$ Selain harus memenuhi unsurunsur perjanjian, untuk sahnya perjanjian harus memenuhi empat syarat yang diatur dalam Pasal 1320 KUHPeryaitu : ${ }^{14}$ a. Sepakat mereka yang mengikatkan dirinya. Dengan sepakat dimaksudkan bahwa pihak-pihak yang mengadakan perjanjian itu harus bersepakat, setuju atau seiasekata mengenai hal-hal yang pokok dari perjanjian yang diadakan itu. Kesepakatan kedua belah pihak dalam suatu perjanjian itu harus diberikan secara bebas. b. Kecakapan untuk membuat perjanjian. Dalam pasal 1330 KUH Pdtdisebutkari orangorang yang tidak cakap untuk rnembuat suatu perjanjian, yaitu: 1) Orang-orang yang belum dewasa, 2) Mereka yang clitaruh di bawah pengampuan, 3) Orang perempuan yang telah kawin (dengan adanya UU No. I Tahun 1974, ketentuan ini tidak berlaku lagi) dan tidak lebih dahulu telah kawin, c) Hal tertentu, d) Sebab yang halal. Syarat nomor 1 dan 2 yakni sepakat mereka yang mengikat dirinya dan kecakapan membuat suatu perjanjian disebut syarat subyektif, karena syarat tersebut merupakan syarat yang harus dipenuhi oleh

11 A. Pitlo, Pembuktian dan Daluwarsa, terjemahan M. Isa Arief, Intermasa, Jakarta, 1986, hlm. 52.

12 Suhardjono, Sekilas Tinjauan Akta Menurut Hukum, Varia Peradilan, Nomor 123, 1995, hlm. 133.

13 Komariah, Op.cit., hlm. 168.

14 Ibid., hlm. 174. 
orangnya (subyek hukum dalam perjanjian). Syarat 3 dan 4 disebut syarat obyektif karena syarat tersebut merupakan syarat yang harus dipenuhi oleh obyek perjanjian.

\section{Apabila}

memenuhi

$$
\text { perjanjian }
$$

$$
\text { syarat obyektif, }
$$

tidak hukumnya adalah perjanjian tersebut batal demi hukum (nietigbaar).Artinya dan semula tidak pernah dilahirkan suatu penjanjian dan tidak pernah ada suatu perikatan. Tujuan para pihak yang mengadakan perjanjian tersebut untuk melahirkan suatu perikatan hukum adalah gagal.Oleh karena itu tidak ada dasar untuk saling menuntut di muka hakim. ${ }^{15}$

Perjanjian yang dituangkan dalam akta notaris dan telah ditandatangani oleh para pihak dan notaris menimbulkan hubungan hukum. Hal mana hubungan hukum tersebut akan tetap mengikat para pihak selama belum ada kesepakatan para pihak untuk membatalkannya atau adanya putusan pengadilan untuk membatalkan akta tersebut. ${ }^{16}$

Seperti yang telah dikemukakan di atas bahwa salinan akta yang tidak sama bunyinya dengan minuta akta dapat dinyatakan batal demi hukum oleh hakim karena ada syarat formil yang tidak terpenuhi. Oleh karena itu, akta notaris dalam hal ini salinan akta maupun minutanya harus terlebih dahulu melalui nilai pembuktian baik lahiriah, formil maupun materiil.
Salinan akta yang tidak sama bunyinya dengan minuta akta yang dinyatakan oleh hakim bahwa akta tersebut batal demi hukum tidak saja mempengaruhi otensitas akta itu sendiri tetapi juga menimbulkan akibat hukum lain terhadap perjanjian yang dituangkan dalam akta.Salinan akta dan minuta akta yang dinyatakan batal demi hukum dapat diartikan bahwa akta tersebut dianggap tidak pernah ada atau tidak pernah dibuat sehingga akta tersebut tidak mengikat para pihak. Begitu juga dengan perjanjian yang merupakan isi dari akta itu sendiri. Namun, dalam hal ini ada 2 (dua) kemungkinan yang dapat terjadi terhadap akta otentik yang salinan aktanya tidak memiliki kesamaan bunyi dengan minutaaktanya, yaitu: 1. akta notaris batal dan perbuatan hukum dalam hal ini perjanjian yang tertuang di dalamnya tidak ikut batal. Hal ini terjadi apabila pihak-pihak menghendaki perbuatan hukum mereka dapat dibuktikan dengan suatu akta otentik, supaya dapat diperoleh suatu pembuktian yang kuat. 2. Akta notarisnya batal dan perbuatan hukum yang tertuang di dalamnya juga ikut batal. Hal ini terjadi jika syarat-syarat perjanjian tidak dipenuhi atau terdapat unsur pemalsuan dalam pembuatan akta tersebut yang merugikan salah satu pihak.Sehingga kedua hal tersebut tergantung dari penilaian hakim dan pembuktian dari para pihak. 
Pembatalan perjanjian oleh salah satu pihak disebut dengan alasan subjektif, karena berhubungan dengan subjek yang menerbitkan perikatan tersebut. Pembatalan dapat terjadi apabila: a) Tidak ada kesepakatan dari para pihak yang membuat perjanjian, baik karena telah menjadi kekhilafan, paksaan atau penipuan pada salah satu pihak dalam pembuatan perjanjian. Hal ini telah diatur dalam Pasal 1321 sampai dengan Pasal 1328 KUH Per. b) Salah satu pihak dalam perjanjian tidak cakap untuk bertindak dalam hukum.

Adanya ketidaksesuaian antara isi Salinan akta dengan minuta aktanya, tidak berakibat langsung dengan batal demi hukum suatu perjanjian yang telah dibuat dihadapan notaris. Hal ini disebabkan, suatu perjanjian dapat dibatalkan atau batal demi hukum. Jika tidak terpenuhi syarat subyektif dan/atau syarat obyektif suatu perjanjianyang diatur di dalam ketentuan Pasal 1320 KUH Per. Syarat subyektif suatu perjanjian adalah kata sepakat di mana mereka yang mengikatkan dirinya dan memiliki kecakapan untuk membuat suatu perikatan. Sepakatatau juga dinamakan perizinan, dimaksudkan bahwa kedua subyek yangmengadakan perjanjian itu harus didasari dengan kesepakatan dan setuju mengenaihal-hal yang pokok dari perjanjian yang diadakan itu, sedangkan kecakapanuntuk membuat suatu perikatan diartikan sebagai setiap orang yang sudahdewasa yaitu berumur 21 (duapuluh satu) tahun atau belum 21 (duapuluh satu)tahun tetapi telah menikah, sehat pikiran (tidak ditaruh dibawah pengampuan). Adapun syarat obyektif suatu Perjanjian adalah suatu hal tertentu dansuatu sebab yang halal. Suatu hal tertentu diartikan bahwa apa yangdiperjanjikan, hak-hak dan kewajiban-kewajiban kedua belah pihak jika timbulsuatu perselisihan. Sedangkan suatu sebab yang halal, dimaksudkan tiada lain dari pada isi perjanjian.

JH. Niewenguis menyatakan bahwa suatu perjanjian yang tidak memenuhi syarat sah sebagaimana yang diatur dalam Pasal 1320 KUH Per, baik menyangkut syarat subyektif maupun syarat obyektif akan mempunyai akibat-akibat sebagai berikut: 17 a. Non eksistensi, yaitu tidak akan lahir perjanjian apabila tidak ada kesepakatan, b. Vernietegbaar atau dapat dibatalkan, apabila perjanjian tersebut lahir karena adanya cacat kehendak atau karena ketidakcakapan. Hal ini terkait dengan unsur subyektif sehingga perjanjian dapat dibatalkan, c. Nietig atau batal demi hukum, apabila terdapat kontrak yang tidak memenuhi syarat subyektif.

Berdasarkan hal tersebut, akta notaris yang memiliki salinan akta yang tidak sama bunyinya dengan minuta akta dapat dinyatakan batal demi hukum karena tidak memenuhi unsur subyektif yaitu sebab yang tidak diperbolehkan atau dilarang oleh undang-undang. Adapun perjanjian yang tertulis dalam akta tersebut batal demi hukum, karena tidak memenuhi syarat obyektif yaitu sebab (causa) yg halal suatu perjanjian dan 
karena hal tersebut notaris dapatdiminta pertanggung jawaban secara hukum dan kode etik profesi notaris.

Mempertimbangkan analisis di atas maka, keabsahan perjanjian yang termuat dalam salinan akta yang bunyinya tidak sama dengan minuta akta dapat dinyatakan batal demi hukum atau dibatalkan oleh kedua belah pihak secara sepakat. Sehingga dengan adanya minuta akta yang dinyatakan batal demi hukum tidak mempengaruhi isi perjanjian selama perjanjian tersebut disepakati oleh kedua belah pihak, memenuhi syarat perjanjian dan tidak mengandung hal-hal yang dilarang oleh undang-undang.

Adanya perjanjian tidak terlepas harus ada subyek dan obyek perjanjian yang merupakan syarat lahirnya perjanjian. Subjek hukum adalah segala sesuatu yang dapat mempunyai hak dan kewajiban menurut hukum atau segala pendukung hak dan kewajiban menurut hukum.Setiap manusia, baik warga negara maupun orang asing adalah subjek hukum. Sedangkan Obyek hukum menurut pasal 499 KUH Per, yakni benda. Benda adalah segala sesuatu yang berguna bagi subyek hukum atau segala sesuatu yang menjadi pokok permasalahan dan kepentingan bagi para subyek hukum atau segala sesuatu yang dapat menjadi obyek hak milik..

Mengenai subyek hukum mempunyai kaitan dengan syarat sah perjanjian yaitu kecakapan dalam membuat perjanjian.
Kecakapan bertindak berhubungan juga dengan kewenangan bertindak dalam hukum.Meskipun kedua hal tersebut secara prinsip berbeda, namun membicarakan kecakapan dalam bertindak tidak terlepas dari kewenangan untuk melakukan tindakan hukum. ${ }^{18}$

Penilaian dalam kecakapan bertindak maupun kewenangan bertindak dalam hukum harus dibuat atau dilakukan secara berurutan. Sebelum subyek hukum dinyatakan cakap bertindak harus pula dicari tahu terlebih dahulu mengenai kecakapan untuk bertindak dalam hukum.Setelah syarat cakap terpenuhi maka seseorang tersebut dapat melakukan perjanjian yang dapat dituangkan dalam akta.

Mengenai kewenangan bertindak dalam hukum dapat dibedakan: ${ }^{19}$ 1) Kewenangan untuk bertindak untuk dan atas namanya sendiri yang berkaitan dengan kecakapannyaunruk bertindak dalam hukum. 2) Kewenangan untuk bertindak selaku kuasa pihak lain yang dalam hal ini tunduk pada ketentuan yang diatur dalam Bab XVI KUH Per tentang pemberian kuasa. 3) Kewenangan untuk bertindak dalam kapasitas sebagai wali atau wakil dari pihak lain.

Mempertimbangkan analisis di atas, maka kedudukan subyek dan obyek hukum dalam salinan akta yang bunyinya tidak sama dengan minuta akta tetap memiliki kekuatan hukum yang sama dengan salinan akta yang bunyinya sama dengan minuta akta. Hal ini dikarenakan 
kedudukan subyek hukum maupun obyek hukum tidak dipengaruhi oleh batalnya suatu akta notaris tetapi karena adanya hal-hal yang tidak sesuai atau dilarang oleh undangundang.

\section{b. Pertanggungjawaban bagi Notaris}

Pentingnya peranan Notaris dalam membantu menciptakan kepastian hukum serta perlindungan hukum bagi masyarakat lebih bersifat preventif yaitu bersifat pencegahan terjadinya masalah hukum, dengan cara menerbitkan akta otentik yang dibuat dihadapannya terkait dengan status hukum, hak, dan kewajiban seseorang dalam hukum yang berfungsi sebagai alat bukti yang paling sempurna di pengadilan apabila terjadi sengketa atas hak dan kewajiban terkait. ${ }^{20}$ Akta yang dibuat oleh atau di hadapan notaris dapat menjadi bukti otentik dalam memberikan perlindungan hukum kepada para pihak manapun yang berkepentingan terhadap akta tersebut mengenai kepastian peristiwa atau kepastian perbuatan hukum itu dilakukan.

Jabatan Notaris merupakan jabatan kepercayaan, sehingga keluhuran serta martabat jabatan notaris harus dijaga dengan baik dalam menjalankan tugas jabatannya maupun perilaku kehidupan notaris sebagai manusia yang secara langsung maupun tidak langsung mempengaruhi martabat jabatan notaris. Notaris yang menjalankan profesi dalam pelayanan hukum kepada masyarakat, perlu mendapat perlindungan dan jaminan demi tercapainya kepastian hukum.

Kepastian melalui hukum bagi perseorangan merupakan tujuan utama dari pada hukum..$^{21}$ Hal ini sejalan degan pendapat Bentham yang menitikberatkan kepastian hukum pada hal-hal yang berfaedah dan bersifat umum. ${ }^{22}$

Peraturan-peraturan yang timbul dari norma hukum (kaedah hukum), dibuat oleh penguasa negara, isinya mengikat setiap orang dan pelaksanaannya dapat dipertahankan dengan segala paksaan oleh alat-alat negara. Keistimewaan dari norma hukum justru terletak dalam sifatnya yang memaksa, dengan sanksinya berupa ancaman hukuman. ${ }^{23}$ Bahwa undang-undang adalah keputusan kehendak dari satu pihak dalam perjanjian, keputusan kehendak dari dua pihak. Dengan kata lain dapat dikatakan bahwa orang terikat pada perjanjian berdasar atas kehendaknya sendiri, pada undang-undang terlepas dari kehendaknya. $^{24}$

Berkaitan dengan hal tersebut, notaris dapat juga diminta pertanggungjawabannya atas kebenaran materiil suatu akta bila nasihat hukum yang diberikannya ternyata dikemudian hari merupakan suatu yang keliru. Serta apabila dalam pembuatan akta tersebut ternyata

20 Sjaifurrachman, Op.cit., hlm. 7.

21 L.J. Van Apeldoorn, Pengantar Ilmu Hukum, Pradnya Paramita, Jakarta, 1981, hlm. 168.

22 C.S.T. Kansil, Op.cit., hlm. 42.

23 Ibid., hlm. 86.

24 L.J. Van Apeldoorn, Loc.cit., hlm. 168. 
notaris tidak memberikan jalan mengenai suatu hukum tertentu yang berkaitan dengan akta yang dibuatnya sehingga salah satu pihak merasa tertipu atas ketidaktahuannya. Untuk itulah disarankan bagi notaris untuk memberikan informasi hukum yang penting yang selayaknya diketahui klien sepanjang yang berkaitan dengan masalah hukum. Lebih lanjut dijelaskan juga bahwa ada hal lain yang juga harus diperhatikan oleh notaris, yaitu yang berkaitan dengan perlindungan hukum notaris itu sendiri, dengan adanya ketidakhati-hatian dan kesungguhan yang dilakukan notaris, sebenarnya notaris telah membawa dirinya pada suatu perbuatan yang oleh undang-undang harus dipertanggungjawabkan. Jika suatu kesalahan yang dilakukan oleh Notaris dapat dibuktikan, maka notaris dapat dikenakan sanksi berupa ancaman sebagaimana yang telah ditentukan oleh undang-undang.

Notaris tidak dapat dilepaskan dari perbuatan yang menyimpang atau perbuatan yang melawan hukum.Karena seorang Notaris tetap seorang manusia biasa yang tak luput dari kesalahan.Notaris harus siap untuk menghadapi jika sewaktu-waktu dijadikan pihak yang terlibat dalam perkara bidang Hukum Perdata maupun Hukum Pidana yang diakibatkan dari produk hukum yang dibuatnya.

Berkaitan dengan salinan akta yang tidak sama bunyinya dengan minuta akta, maka hal ini merupakan kesalahan notaris dalam membuat akta sehingga menyebabkan pihak lain mengalami kerugian dapat termasuk perbuatan melawan hukum karena kelalaian.

Berkaitan dengan seorang notaris membuat salinan akta yang bunyinya tidak sama dengan minuta aktanya, maka notaris tersebut telah melakukan pelanggaran kewajiban jabatannya di mana dalam menjalankan jabatannya notaris memiliki kewajiban untuk bertindak jujur, saksama, mandiri, tidak berpihak, dan menjaga kepentingan pihak yang terkait dalam perbuatan hukum serta penuh rasa tanggung jawab dan menerapkan prinsip kehati-hatian dalam membuat akta. Dengan demikian, notaris tersebut dibebani tanggung jawab, yaitu tanggung jawab secara Perdata, berdasarkan UU Nomor 2 Tahun 2014 dan Kode Etik Notaris Ikatan Notaris Indonesia bahkan juga tanggung jawab secar

Selain itu, sebagaimana yang telah dijelaskan tersebut di atas, bahwa salinan akta yang dibuat oleh Notaris didasarkan pada minuta akta hal ini didasarkan dari ketentuan Pasal 1 ayat (9) UU Nomor 2 Tahun 2014 bahwa:

"Salinan Akta adalah salinan kata demi kata dari seluruh akta dan pada bagian bawah salinan akta tercantum frasa 'diberikan sebagai salinan yang sama bunyinya'",

Berkaitan dengan hal tersebut, notaris tidak langsung seketika membuat Salinan akta berdasarkan Minuta yang telah ia tandatangani. Hal yang Notaris lakukan adalah merapikan dengan mencatat perubahanperubahan yang ada di dalam minuta akta dalam selembar kertas, yang dapat terdiri dari 
penambahan, pencoretan dan penggantian, hal mana perubahan tersebut dinamakan "renvoi" yang biasanya ditulis disisi kiri akta. Perubahan-perubahan tersebut yang kemudian dimasukkan (Inserting) dalam salinan akta yang akan dibuat, sehingga di dalam salinan akta sudah tidak ada lagi renvoiseperti pada minuta akta sebelumnya. Dalam proses pembuatan salinan akta, notaris melakukan penyesuaian, dengan mencocokkan salinan akta dengan minutanya.

Sehingga kesesuaian terhadap bunyi dari salinan akta terhadap minutaaktanya dapat tercapai. Hal ini dilakukan untuk mencegah adanya kekurangtelitian atau kekhilafan yang dapat menimbulkan masalah dikemudian hari serta salinan akta yang dibuat oleh Notaris dapat dipertanggungjawabkan secara hukum dan memberi kepastian hukum terhadap orang yang berkepentingan langsung pada akta, ahli waris, atau orang yang memperoleh hak terhadap akta tersebut.

Mempertimbangkan analisis di atas, maka apabila notaris membuat salinan akta tidak sesuai dengan minutaAktanya, maka notaris telah melakukan pelanggaran terhadap kewajiban dalam menjalankan jabatannya yang telah ditentukan baik di dalam UU Nomor 2 Tahun 2014 Pasal 16 ayat (1) huruf (a) maupun Kode Etik Notaris, di mana Notaris dalam menjalankan jabatannya, memiliki kewajiban untuk bertindak jujur dengan tidak melakukan perbuatan yang menyimpang dari kepercayaan yang diberikan oleh masyarakat, Saksama dapat diartikan bahwa seorang notaris harus cermat di dalam menguasai peraturan perundang-undangan agar Akta otentik yang dibuatnya tidak melanggar atau bertentangan dengan Peraturan perundangundangan yang berlaku, berarti notaris dari waktu ke waktu wajib mengikuti Peraturan perundang-undangan yang dikeluarkan oleh pemerintah yang berhubungan dengan profesi Notaris, Mandiri yaitu notaris dalam menjalankan profesinya tidak terikat dengan salah satu lembaga/institusi, Tidak berpihak di mana dalam membuat akta notaris, isinya tidak boleh menguntungkan salah satu pihak dan merugikan pihak dan menjaga kepentingan pihak yang terkait dalam perbuatan hukum, Penuh rasa tanggung jawab serta harus pula menerapkan prinsip kehati-hatian dalam setiap tindakan yang ia lakukan.

Hal tersebut berkaitan dengan jabatan dari seorang Notaris yang merupakan suatu jabatan kepercayaan dari masyarakat dan secara jelas telah disebutkan bahwa akta notaris memiliki dan mempunyai karakter yuridis tersendiri dalam pembuatannya dengan memakai lambang Negara Burung Garuda sebagai cap atau stempel aktanya, yang merupakan suatu bukti adanya pendelegasian tugas dari Negara untuk urusan perbuatan hukum tertentu kepada Notaris, dan juga untuk adanya suatu jaminan kepastian hukum, dan adanya suatu alat bukti yang otentik dalam bentuk suatu legalitas formal.

Berdasarkan ketentuan Pasal 51 ayat (1), (2), (3) UU Nomor 2 Tahun 2014, menentukan bahwa notaris berwenang untuk membetulkan 
kesalahan tulis dan/atau kesalahan ketik yang terdapat pada Minuta Akta yang telah ditandatangani, Pembetulan mana dilakukan dengan membuat Berita Acara dan memberikan catatan tentang hal tersebut pada Minuta Akta asli dengan menyebutkan tanggal dan nomor Akta Berita Acara Pembetulan serta Salinan Akta Berita Acara tersebut wajib disampaikan kepada para pihak. Sedangkan perubahan terhadap Salinan Akta yang telah ditandatangani tidak diatur di dalam UU Nomor 2 Tahun 2014.Hal ini dilakukan dengan tujuan untuk melindungi kepentingan para pihak yang sengaja datang menghadap kepada notaris untuk dibuatkan akta agar memperoleh sifat otentik karena kedudukan notaris tersebut sebagai pejabat umum, karena kepada para pihak sebagai tanda bukti telah terjadinya suatu perbuatan hukum dihadapan Notaris hanya diberikan salinan Akta. Dengan demikian, jika Salinan akta yang telah ditandatangani dan diberikan kepada para pihak dapat diubah-ubah dikemudian hari dengan mudahnya oleh notaris, maka tidak akan ada kepastian hukum bagi para pihak yang membuat Akta dihadapan notaris tersebut, serta fungsi notaris sebagai jabatan kepercayaan dari masyarakat untuk membuat akta otentik tidak dapat dilaksanakan dengan baik karena kepastian hukum dari para pihak yang membuat akta dihadapan notaris dapat berubah sewaktu-waktu.

Salinan akta yang keluar dan tidak sama bunyinya dengan minuta akta merupakan kesengajaan atau kelalaian seorang Notaris, sehingga kesengajaan atau kelalaian dalam melakukan tugas dan jabatan yang menyebabkan adanya suatu kerugian maka Notarisharus dapatmempertanggungjawabkan perbuatannya tersebut.

Tindakan tersebut tidak hanya mengakibatkan akta notaris yang seharusnya otentik menjadi akta di bawah tangan atau batal demi hukum, namun notaris juga harus menerima akibat hukum dari akta tersebut. Akibat hukum bagi notaris yang melakukan pelanggaran adalah dapat berbentuk sanksi. Sanksi tersebut berwujud tanggung jawab notaris terhadap kesalahan yang berupa tindakan/ perbuatan baik dikarenakan kesengajaan maupun kelalaian.

Berkaitan dengan pertanggungjawaban notaris, secara hukum hal demikian tidak diatur secara jelas dan tegas baik oleh undangundang terdahulu maupun undang-undang yang sekarang sehingga apabila pelanggaran notaris dapat dibuktikan, maka notaris tersebut harus dapat mempertanggungjawabkan perbuatannya.Terkait dengan kesalahan notaris, maka yang digunakan adalah beroepsfout. Istilah tersebut digunakan untuk kesalahan yang dilakukan oleh profesional dan jabatan-jabatan khusus termasuk notaris. ${ }^{25}$

Kesalahan yang dilakukan oleh notaris memiliki hubungan dengan keadaan yang dimiliki oleh notaris berkaitan dengan 3 kecerdasan manusia yang juga harus ada dalam diri seorang notaris.Kecerdasan tersebut 
meliputi kecerdasan spiritual, intelektual dan emosional. Apabila notaris mampu menggunakan ketiga kecerdasan tersebut secara seimbang akan membawa kepada 3 kemampuan, yaitu: a) mampu dalam mengerti nilai dan akibat-akibat yang ditimbulkan dari perbuatannya sendiri. b) mampu untuk menyadari apa yang diperbuatnya tidak diperbolehkan dalam pandangan masyarakat.

c) mampu untuk memiliki niat yang baik dalam melakukan perbuatan itu.

Kesengajaan (dolus) menurut hukum pidana adalah perbuatan atau tindakan yang disadari, dimengerti dan diketahui sebagai demikian sehingga tidak ada unsur salah sangka atau salah paham. ${ }^{26}$ Sedangkan kealpaan (culpa) adalah terjadinya suatu perbuatan atau tindakan dikarenakan kurang hati-hati dan perbuatan tersebut bertentangan dengan kewajibannya. Perbuatan atau tindakan tersebut juga tidak terpikirkan terlebih dahulu mengenai akibatnya. ${ }^{27}$

Mempertimbangkan uraian di atas, maka notaris yang membuat salinan akta yang tidak sama bunyinya dengan minuta akta merupakan kesengajaan. Hal ini dikarenakan hanya notaris saja yang memiliki kewenangan untuk membuat salinan akta tersebut.Maka dari itu, notaris yang melakukan hal tersebut sudah melebihi batas kewenangannya yang telah diberikan oleh Undang-undang Jabatan Notaris.
Berkaitan dengan hal tersebut, maka harus ada tanggung jawab dari notaris. Di mana tanggung jawab tersebut berupa sanksi. Sanksi merupakan kewajiban yang harus dicantumkan dalam setiap aturan hukum dan aturan hukum tidak dapat ditegakkan tanpa adanya sanksi.Hal ini dikarenakan sanksi adalah suatu paksaan yang dapat membuat pelanggarnya menyadari bahwa tindakan atau perbuatannya tidak sesuai dengan aturan hukum yang berlaku. Sanksi yang ditujukan kepada notaris bertujuan selain agar notaris melaksanakan jabatannya sesuai dengan UU nomor 30 Tahun 2004 dan UU Nomor 2 Tahun 2014, juga untuk melindungi masyarakat dari tindakan notaris yang merugikan. Sanksi tersebut juga bertujuan untuk menjaga martabat lembaga notaris sebagai lembaga kepercayaan.

\section{Simpulan}

Kedudukan dari salinan akta notaris yang semula dapat digunakan sebagai alat bukti yang sempurna menjadi tidak sempurna dikarenakan salinan akta tersebut tidak sama bunyinya dengan minuta akta, sehingga salinan akta tersebut tidak memnuhi syarat formil dan materiil prosedur pembuatan akta. Hal ini dapat mengakibatkan salinan akta tersebut dinyatakan batal demi hukum. Konsekuensi yuridis perjanjian yang salinan akta notaris tidak sama bunyinya dengan minuta akta yaitu:

26 Muljatno, Asas-asas Hukum Pidana, Rineka Cipta, Jakarta, 1993, hlm. 171.

27 Roeslan Saleh, Perbuatan Pidana dan Pertanggungjawaban Pidana Dua Pengertian Dasar dalam Hukum Pidana), Aksan Baru, Jakarta, 1983, hlm. 125. 
perjanjian tersebut juga dapat dinyatakan batal demi hukum sepanjang ada kesepakatan dari para pihak untuk membatalkannya karena mengakibatkan kerugian bagi para pihak dan mengandung unsur kekhilafan dan penipuan.
Notaris memiliki sanksi yang berupa pertanggungjawaban apabila notaris tersebut menyalahgunakan wewenangnya baik sanksi administrasi, sanksi perdata maupun sanksi pidana.

\section{DAFTAR PUSTAKA}

A. Pitlo, 1986, Pembuktian dan Daluwarsa, terjemahan M. Isa Arief, Intermasa, Jakarta.

Anshori, Abdul Ghofur, 2009, Lembaga Kenotariatan Indonesia Perspektif Hukum dan Etika, Cetakan Ke-1, UII Press, Yogyakarta.

Habib Adjie, 2008, Sanksi Perdata dan Administratif terhadap Notaris Sebagai Pejabat Publik, Refika Aditama, Bandung.

I R. Soegondo Notodisoerjo, 1993, Hukum Notariat di Indonesia, RajaGrafindo Persada, Jakarta.

Irfan Fachrudin, 1994, Kedudukan Notaris dan Akta-aktanya dalam Sengketa Tata Usaha Negara, Varia Peradilan Nomor 122.

Komariah Andasmita, 1983, Notaris Selayang Pandang, Cetakan $\mathrm{Ke}-2$, Alumni, Bandung.

L.J. Van Apeldoorn, 1981, Pengantar Ilmu Hukum, Pradnya Paramita, Jakarta.

Muljatno, 1993, Asas-asas Hukum Pidana, Rineka Cipta, Jakarta.
Republik Indonesia, 1998, Kitab Undangundang Hukum Pidana (KUHP), Terjemahan R. Soesilo, Pelita, Bogor. Roeslan Saleh, 1983, Perbuatan Pidana dan Pertanggungjawaban Pidana Dua Pengertian Dasar dalam Hukum Pidana), Aksan Baru, Jakarta.

Sjaifurrachman, 2011 , Aspek Pertanggungjawaban Notaris dalam Pembuatan Akta, Mandar maju, Bandung.

Subekti, 1980, Pokok-pokok Hukum Perdata, Intermasa, Jakarta.

Sudikno Mertokusumo, 1999, Mengenal Hukum Suatu Pengantar, Liberty, Yogyakarta.

Suhardjono, 1995, Sekilas Tinjauan Akta Menurut Hukum, Varia Peradilan, Nomor 123.

\section{Peraturan Perundang-undangan}

Undang-undang Republik Indoneia Nomor 2 tahun 2014 tentang Perubahan terhadap Undang-undang Nomor 30 Tahun 2004 tentang Peraturan Jabatan Notaris. 